\title{
LiDAR based urban vegetation mapping as a basis of green infrastructure planning
}

\author{
Krzysztof Pyszny ${ }^{1, *}$, Mariusz Sojka ${ }^{2}$, and Rafat Wróżyński ${ }^{2}$ \\ ${ }^{1}$ EnviMap, ul. Piątkowska 118/31, 60-649 Poznań, Poland \\ ${ }^{2}$ Faculty of Environmental Engineering and Spatial Management, Poznań University of Life Sciences, ul. Piątkowska 94, \\ 60-649 Poznań, Poland
}

\begin{abstract}
Planning green infrastructure in the cities is a challenging task for planners and city managers. Developing multifunctional green space systems provide many benefits including: increasing water retention, mitigating urban heat island effect, microclimate regulation, reducing air, water and noise pollution and conservation biodiversity. The greenery in the city also have an impact on human health. The paper presents the possibilities of using LiDAR data mapping vegetation density in urban areas on the example of Gorzów Wielkopolski (Poland). Maps made as a result of processing the point clouds obtained from airborne laser scanning represents the most accurate, comprehensive and detailed assessment of Gorzów Wielkopolski vegetation cover to date and establishes the baseline for greenery governance and planning of green infrastructure in the city.
\end{abstract}

\section{Key words:}

LIDAR data, vegetation mapping, urban greenery planning, green infrastructure, spatial analysis, point cloud analysis, green governance and planning

\section{Introduction}

Globally, more people live in urban than in rural areas, with $55 \%$ of the world's population residing in urban areas in 2018. In 1950, 30\% of the world's population was urban, and by $205068 \%$ of the world's population is projected to be urban [1]. There is a need to enhance liveability and sustainability in cities, ensuring that urban spaces are safe and attractive places for living and working. However, climate change and urbanisation are putting this at risk through problems such as increasing flood risk, heat stress, water shortages and air pollution [2]. Greenery in cities, especially urban trees, has a number of regulatory functions. For example, urban trees reduce the temperature through shading and evapotranspiration [3-4] and improve air quality through absorption of gaseous pollutants and interception of particles on plant surfaces [5]. Storm water runoff is attenuated by rain water interception and storage in urban vegetation which reduces flooding damage. Green stormwater infrastructure mitigates urbanization impacts by disconnecting impervious areas from storm sewer systems and using the hydrologic cycle components to reduce runoff volume and pollutant loads [6-9]. Given the associations between vegetated land cover and the biophysical and social processes of urban systems, there exists an ongoing demand for effective urban vegetation mapping and classification techniques [10].

The availability of high-resolution LiDAR data and the development of tools for its analysis make it possible to create accurate DEM [11, 12] and maps of urban vegetation [13-14]. Vegetation data obtained from the processing of LiDAR point clouds can be supported by data collected from satellite level [15] and SfM data [16]. Such maps allow to determine areas where it is recommended to plan and implement green and blue infrastructure. To enhance connectivity green area and ecosystem services, urban green spaces should be linked by corridors, forming a network facilitating dispersal and movement [17] water, plants, animals and people.

The aim of this study was to indicate the possibility of using LiDAR data in the urban inventory of medium and high vegetation and indicate the areas requiring introduction of new vegetation to create a coherent model of urban greenery.

\footnotetext{
Corresponding author: pyszny@envimap.pl
} 


\section{Characteristics of study area}

The city of Gorzów Wielkopolski is located in northwestern Poland. The city had 124295 inhabitants. Gorzów Wielkopolski is located on seven hills. The city is crossed by the Warta River, dividing it into two parts: a strongly undulating northern part, with the elevation of 23.0 to $82.0 \mathrm{~m}$, and the southern, left-bank lowland part of the city, with an average elevation of $19 \mathrm{~m}$, including a flat flood plain with numerous preserved old riverbeds. 'The city of parks and gardens' is what Gorzów Wielkopolski used to be called [18].

\section{Materials}

To estimate the density of greenery, data from airborne laser scanning (LiDAR) as a point cloud in .LAS file format were used. Data in the form of binary files were obtained from the Polish Central Office of Geodesy and Cartography in accordance with standard 1.2, published in 2008 by the American Society for Photogrammetry and Remote Sensing (ASPRS). The point cloud was developed on the basis of measurements carried out in the years 2011 - 2013. The density varied and ranged from 4 to 12 points $\mathrm{m}^{2}$. The average altitude error does not exceed $0.15 \mathrm{~m}$. The point cloud contains class data of given point and the reflection intensity in the red, green and blue colors (RGB values), obtained from aerial photographs. The point classes were defined in accordance with the LAS format shown in Table 1.

Table. 1. ASPRS Standard LiDAR Point Classes

\begin{tabular}{|c|c|}
\hline $\begin{array}{c}\text { Classification } \\
\text { value }\end{array}$ & Description \\
\hline 0 & Created, never classified \\
\hline 1 & Unclassified \\
\hline 2 & Low Vegetation $(0-0.40)$ \\
\hline 3 & Medium Vegetation $(0.40-2.00 \mathrm{~m})$ \\
\hline 4 & Low Pointation $(>2 \mathrm{~m})$ \\
\hline 5 & Model Key-point (mass points) \\
\hline 6 & Water \\
\hline 7 & Reserved for ASPRS Definition \\
\hline 8 & Reserved for ASPRS Definition \\
\hline 9 & Overlap Points \\
\hline 10 & Reserved for ASPRS Definition \\
\hline 11 &
\end{tabular}

The accuracy of the points classification is not less than $95 \%$.

In the analysis, a total of 341 LiDAR sheets with an area of $0.25 \mathrm{~km}^{2}$ each were used (Fig. 1). The average density of points is 7 points $/ \mathrm{m}^{2}$. In total, the analyzed area consists of $2.23 \cdot 10^{9}$ points from laser scanning, of which the medium and high vegetation is represented by $0.51 \cdot 10^{9}$ points, which is $23 \%$ of all points.

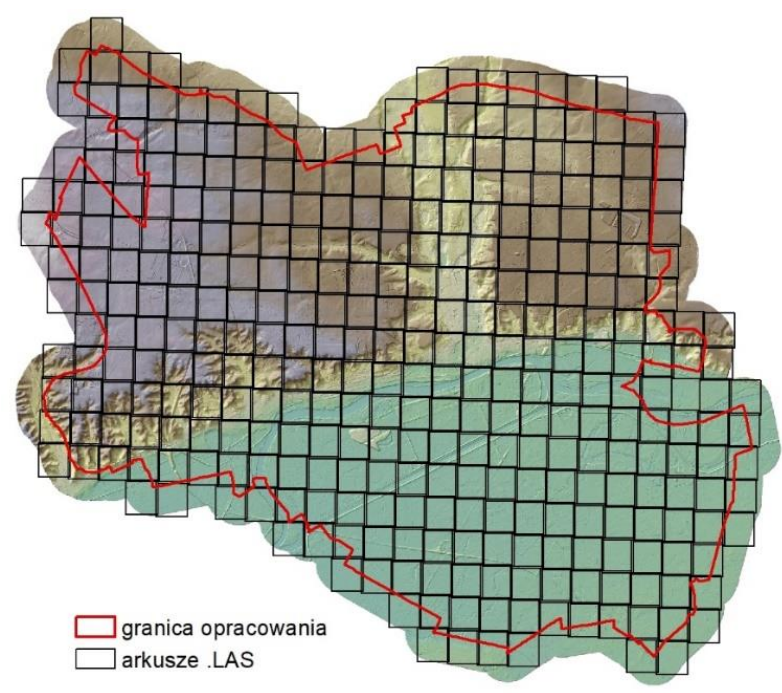

Fig. 1. Division of Gorzów Wielkopolski area into LIDAR data sheets

\section{Methods}

In order to estimate the density of vegetation, the ratio of the number of points representing vegetation to the number of all points (vegetation and ground points) in a given area was calculated. In the first step, points classified as points lying on the ground and points representing low, medium and high vegetation were distinguished from the integrated point clouds. An exemplary visualization of the classification of point clouds is presented in Figure 2.
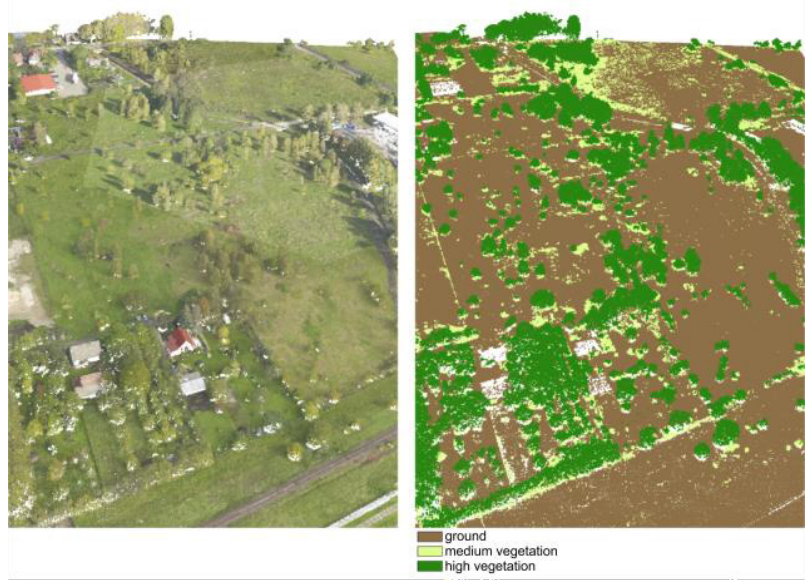

Fig. 2. LIDAR data visualisation a) RGB colour, b) point classification

Then the analyzed area was divided into parts (cells) in the process of rasterization. It is assumed that the resolution of the raster should be at least four times greater than the average distance between the points of the point cloud. In this study the resolution of 10 meters was used. The geoprocessing summed up the number of points representing vegetation (medium and high) and the number of points lying on the ground in each raster cell. Vegetation density was calculated by dividing the number of points representing vegetation by the number 
of all points in each raster cell. The results are presented as a percentage values (Fig. 3). In the next stage, a vegetation density map in the form of hexagons measuring $100 \mathrm{~m}$ was created (Fig. 4).

\section{Results}

The potential connectors/corridors suitable for green infrastructure development were delimitated, using

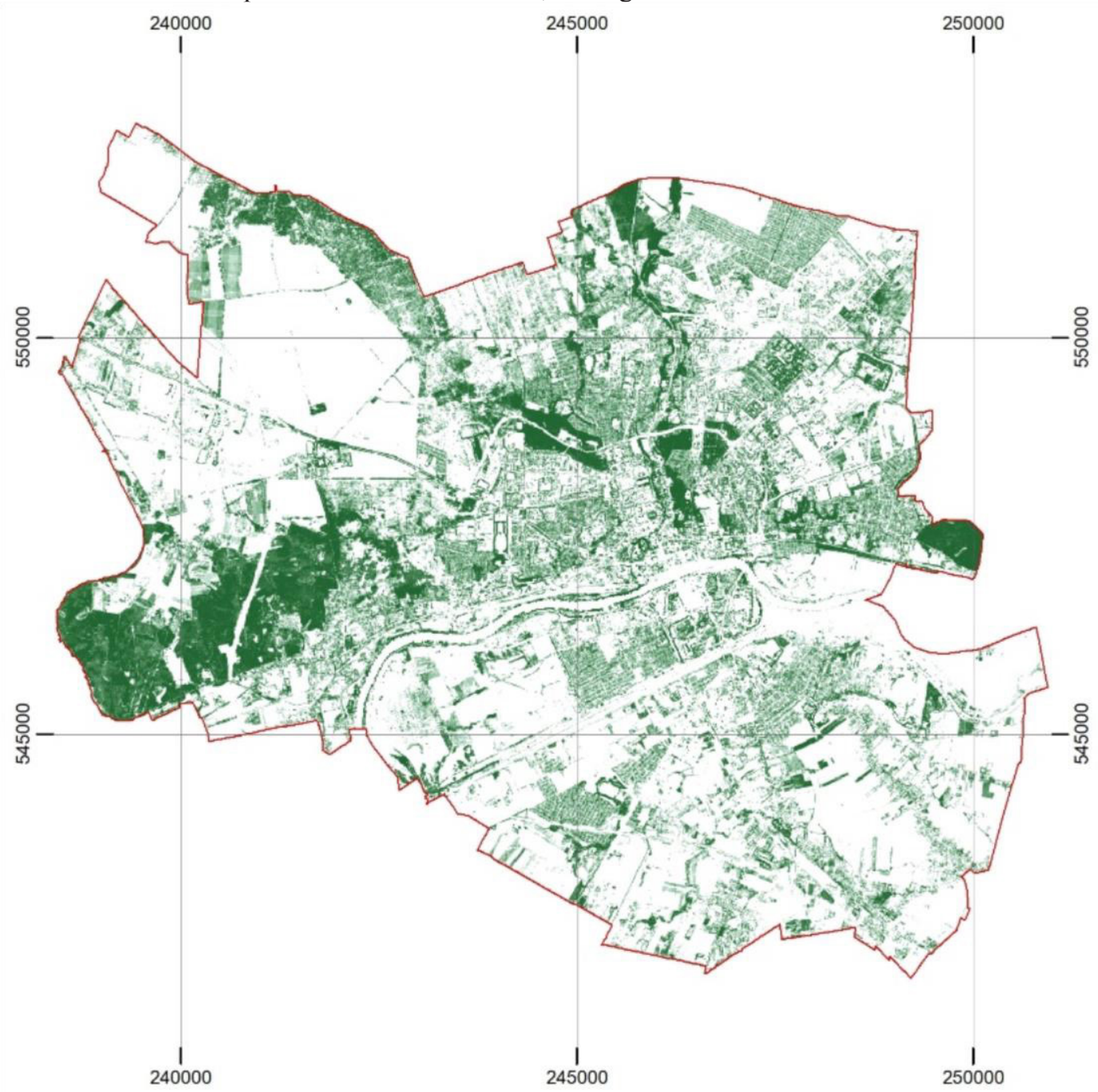

\section{Explanations}

vegetation density \%

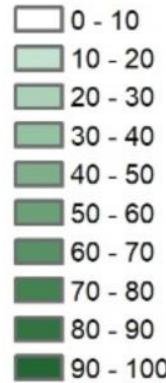

Fig. 3. Percentage of vegetation density in a $10 \mathrm{~m}$ raster 


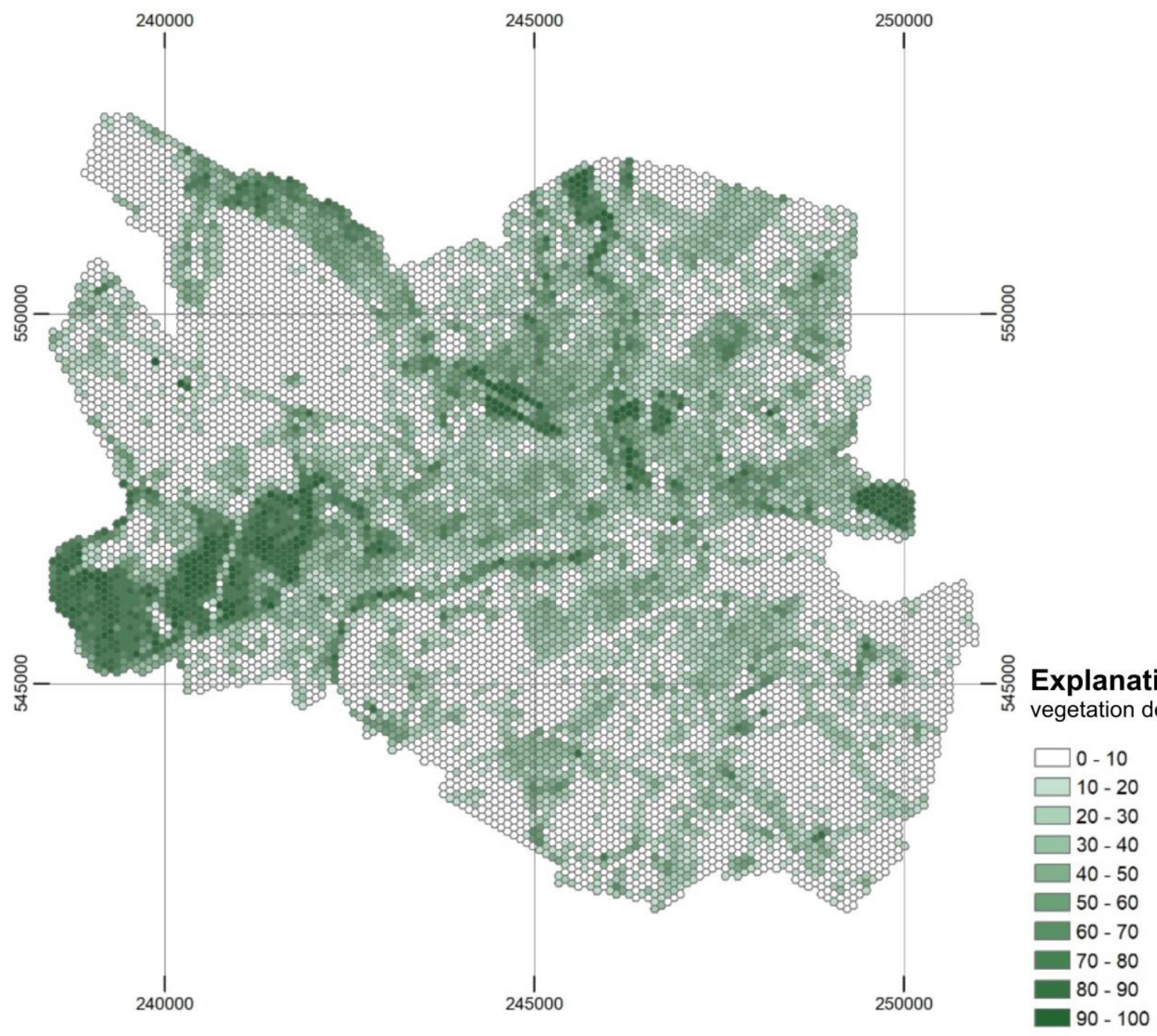

Fig. 4. Percentage of vegetation density in a $100 \mathrm{~m}$ hexagon

On the basis of the performed analyses, a proposition of creating a coherent system of green infrastructure in the city was presented.

Tabel 2. Areas of urban greenery, which were taken into account in the process of creating a greenery system in the

\begin{tabular}{|c|c|}
\hline & Gorzów Wielkopolski \\
\hline \multirow{4}{*}{ 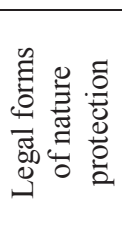 } & Nature 2000 areas \\
\hline & Nature reserve - Gorzowskie Murawy \\
\hline & $\begin{array}{c}\text { Protected landscape areas - Dolina Warty i } \\
\text { Dolnej Noteci }\end{array}$ \\
\hline & $\begin{array}{l}\text { Ecological arable landa „Gorzowskie } \\
\text { Murawy Kserotermiczne” }\end{array}$ \\
\hline \multirow{8}{*}{ 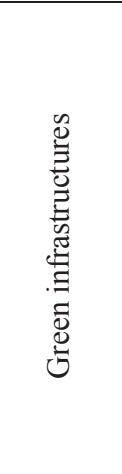 } & Existing parks \\
\hline & $\begin{array}{l}\text { Parks designed in local spatial development } \\
\text { plans }\end{array}$ \\
\hline & Existing squares and greens \\
\hline & $\begin{array}{c}\text { Squares and greens designed in local spatial } \\
\text { development plans }\end{array}$ \\
\hline & $\begin{array}{l}\text { Historic gardens and other historic green } \\
\text { areas }\end{array}$ \\
\hline & $\begin{array}{l}\text { Existing accompanying greenery in the areas } \\
\text { of the ecological corridors }\end{array}$ \\
\hline & forests \\
\hline & Trees and bushes, semi-natural communities \\
\hline
\end{tabular}

\begin{tabular}{|c|c|}
\hline \multirow{y}{*}{ Existing and projected cemeteries } \\
\cline { 2 - 3 } & $\begin{array}{c}\text { Allotment gardens } \\
\text { Undeveloped areas - planned to be used for } \\
\text { developing elements of green infrastructure }\end{array}$ \\
\cline { 2 - 2 } & $\begin{array}{c}\text { Developed areas - planned to be used for } \\
\text { developing elements of green infrastructure }\end{array}$ \\
\hline
\end{tabular}

The areas suitable for the development of green infrastructure were determined (Figure 5). Their realization is anticipated to enhance and integrate the urban green system. It is highly recommended to enrich the existing green system with the new links and to strengthen the existing but poorly developed structures.

As a result of the performed analysis, two types of complementary areas were determined. Areas of the first type, currently not developed, were indicated to develop medium and high vegetation in at least $50 \%$ of their area. The second type of areas consists of the boundaries of the buildings and/or technical infrastructure, mostly roads. There is no exact recommendation to what percentage the existing system should be complemented with elements of green infrastructure. However, it is advised to take action to implement green infrastructure

\footnotetext{
* Corresponding author: pyszny@envimap.pl
} 
as much as possible. In developed areas, the realization of green areas, squares, green roofs etc. is advocated. Along the communication routes, trees and shrubs are suggested to be planted. Figure 5 presents the density of high and medium vegetation exceeding $40 \%$ of the hexagon's surface coverage and includes the existing green areas (listed in Table 2) - the color green. The areas which are mostly undeveloped, but predisposed for green infrastructure development are shown in light green, while the developed areas are presented in red.

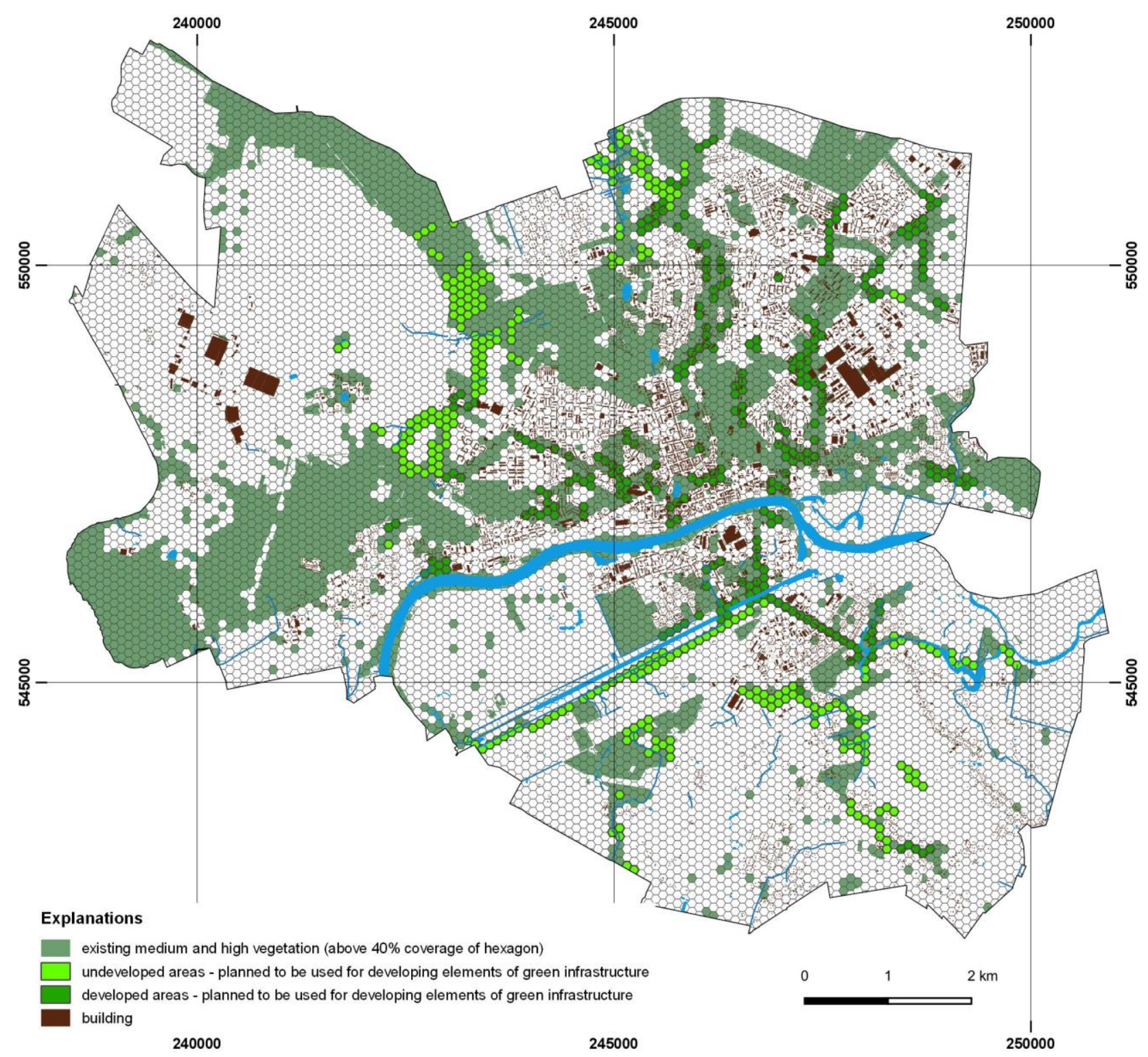

Fig. 5. Corridors predisposed for the implementation of green infrastructure elements

\section{Conclusions}

The LiDAR based vegetation mapping represents the most accurate, comprehensive and detailed accounting of Gorzów Wielkopolski vegetation cover to date. It provides the foundation for understanding the quantity, distribution and configuration of medium and high vegetation within Gorzów Wielkopolski and establishes the baseline for greenery governance, planning green and blue infrastructure and future canopy cover change analysis.

\section{Acknowledgments}

Publication is funded by the Polish National Agency for Academic Exchange under the International Academic Partnerships Programme from the project „Organization of the 9th International Scientific and Technical Conference entitled Environmental Engineering, Photogrammetry, Geoinformatics - Modern Technologies and Development Perspectives".

The paper is based on data provided by the City Council of Gorzów Wielkopolski. The results of the research were presented in an "Ecophysiographic study of the city of Gorzów Wielkopolski" prepared by the authors of this article. The analyses were used in works on the study of conditions and directions of spatial development of the city of Gorzów 
Wielkopolski. We would like to thank the workers of the Gorzów Wielkopolski City Council for making the data available.

\section{References}

1. United Nations, Department of Economic and Social Affairs, Population Division (2018). World Urbanization Prospects: The 2018 Revision, Online Edition. Available from https://esa.un.org/unpd/wup/PublicationsFiles/WUP20 18-KeyFacts.pdf (Jun. 15, 2019).

2. IPCC, 2012. In: C.B., P.M.M., Barros, V., Stocker, T.F., Qin, D., Dokken, D.J., Ebi, K.L., Mastrandrea, M.D., Mach, K.J., Plattner, G.-K., Allen, S.K., Tignor, M. (Eds.),Managing the Risks of Extreme Events and Disasters to Advance Climate Change Adaptation. A Special Report of Working Groups I and II of the Intergovernmental Panel on Climate Change. Cambridge University Pres, Cambridge and New York.

3. E. D, Bowler, L Buyung-Ali, T. M. Knight, A. S. Pullin, Landsc Urban Plan, 97, 147-155 (2010)

4. S. Gillner, J. Vogt, A. Tharang, S. Dettmann, A. Roloff, Landsc Urban Plan, 143, 33-42 (2015)

5. V.M. Jayasooriya, A. W. M Ng, S. Muthukumaran, B. J. C. Perera, URBAN FOR URBAN GREE, 21, 34-47 (2017)

6. A. Berland, S.A. Shiflett, W.D. Shuster, A.S. Garmestani, H.C. Goddard, D.L. Herrmann, M.E. Hopton, Landsc. Urban Plan., 162, 167-177 (2017)

7. C.P. Muerdter, C.K. Wong, G.H. LeFevre, Water Res. Technol. 4 (5), 592-612 (2018)

8. J. Kazak, J. Chruściński, Sz. Szewrański, Sustainability 10(12) (2018)

9. T. Kałuża, M. Sojka, P. Strzeliński, R. Wróżyński. Water, 10(6) (2018).

10. T.R. Tooke, N.C. Coops, N.R. Goodwin, J.A. Voogt. Remote Sens Environ, 113, 398-407 (2009)

11. Cz. Przybyła, K. Pyszny. ROCZ OCHR SR. 15, 14891510 (2013)

12. Z. Walczak, M. Sojka, I Laks. ROCZ OCHR SR, 15, 2711-2724 (2013)

13. J. Klingberg, J. Konarska, F. Lindberg, L. Johansson, S. Thorsson, URBAN FOR URBAN GREE, 26, 31-40 (2017)

14. E.G. Parmehr, M.Amati, E.J. Taylor, S.J.Livesley, URBAN FOR URBAN GREE, 20, 160-171 (2016)

15. M. Sojka, J. Jaskuła, R.Wróżyński, B. Waligórski. CARPATH J EARTH ENV 14(1), 39-50 (2019)

16. R. Wróżyński, K. Pyszny, M. Sojka, C. Przybyła, S. Murat-Błażejewska. OPEN GEOSCI, 9, 281-294 (2017)

17. A. F. Bennett. Linkages in the Landscape. The Role of Corridors and Connectivity in Wildlife Conservation (1999)

18. W. Piworun. Gorzów Wielkopolski: miasto parków i ogrodów (1998) 